https://doi.org/10.15407/scin16.02.020

BURKYNSKYI, B.V.', SOKOLOVSKA, Z.M.', ALYOKHIN, A.B. ${ }^{2}$, KHUMAROVA, N.I.', and KAPUSTYAN, I.V. ${ }^{2}$

' Institute of Market Problems and Economic-Ecological Research, the NAS of Ukraine, 29, Frantsuzskiy Bvrd, Odesa, 65044, Ukraine,

+380 48722 6611, burkinskij@nas.gov.ua

${ }^{2}$ Odesa National Polytechnic University, 1, Shevchenko Ave., Odesa, 65044, Ukraine,

+380 487058358 , nadin_zs@te.net.ua

\title{
TOOLS OF DECISION MAKING IN THE FIELD OF STRATEGIC ADVERTISEMENT OF PHARMACEUTICAL ENTERPRISES
}

Introduction. The evolution of the modern information and communication technologies contributes to enhancement of advertising strategies, as effective tools of pharmaceutical marketing.

Problem Statement. The need to take into account the nonlinear dynamic nature of advertising processes and presence the influence of numerous stochastic factors in market environment of pharmaceutical enterprises with the impossibility of obtaining an unambiguous analytical solution put forward problem of attracting a special mathematical apparatus for research.

Purpose. To study processes of decision-making in the field of strategic advertising of pharmaceutical enterprises using the apparatus of simulation modeling.

Materials and Methods. The research is based on using multi approach paradigm of simulation in the software environment of AnyLogic. The materials of pharmaceutical company OJSC "Farmak" are used in the course of simulation experiments.

Results. The expediency of attracting modeling methods as tools of making strategic advertising decisions is substantiated. A simulation model-simulator is proposed, developed using a combination of Agent and SystemDynamic approaches on the AnyLogic software platform. The decision-making process is illustrated by the results of various types of simulation experiments. The main areas of use the simulator: monitoring and predicting the reaction of target audiences to product advertising; effectiveness control of research on new and re-releasing existing medicines in response to market reactions and preferences of potential clients; optimization of advertising budget with justification of expediency of its redistribution between original and generic preparations.

Conclusions. The efficiency of using simulation models-simulators as tools for the formation of advertising strategies has been proved. The development can be recommended for implementation by pharmaceutical companies.

Keywords: advertising strategy, pharmaceutical enterprise, simulation modeling, model-simulator, simulation experiments.

Цитув вання: Burkynskyi B.V., Sokolovska Z.M., Alyokhin A.B., Khumarova N.I., and Kapustyan I.V. Tools of Decision Making in the Field of Strategic Advertisement of Pharmaceutical Enterprises. Nauka innov. 2020. V. 16, no. 2. P. 20-32. https://doi.org/10.15407/scin16.02.020 
The pharmaceutical industry is one of the sectors of the domestic economy that demonstrates positive development dynamics, despite the existing problems, such as imperfection of the applicable legislation; lack of funding; low solvency of the population; significant dependence on imports, and increased competition in the pharmaceutical market.

The pharmaceutical companies are one of the most high-tech industries with a rapidly updated product line. Accordingly, their interest in such business development strategies as research and development (in particular, the development of innovative products) is growing, which is accompanied by a deepening of production localization with an active search for cost optimization strategies and marketing strategies for market research and product promotion.

An effective tool and important component for pharmaceutical marketing is advertising, which reaches a new level with the advent of modern information and communication technologies, aimed at users with complex behaviors, prone to interactive communication and changing benefits. Significant segmentation of the pharmaceutical market, due to the diversification of product lines, sets forth special requirements for the formation of advertising strategies and establishes their close relationship with the product strategies of pharmaceutical enterprises.

Making decisions in the field of strategic advertising involves a thorough study of the target audience (potential users) of products, timely forecasting of the dynamics of their changes. A parallel process tracks the life cycle of each product from a range of enterprises from the stages of research and development to entering the market and the duration of its stay. Advertising may extend or reduce the age of the product on the market. In turn, market trends determine the feasibility of increasing or decreasing the advertising budget and the technology of its use (or termination of use). The above processes occur under the influence of many stochastic factors of the internal and external environment of pharmaceutical companies. Therefore, it is necessary to predict the dynamics of the relevant sectors of the pharmaceutical market (target audiences, product flows) in the face of risk and uncertainty in order to make informed decisions in the process of determining and implementing both marketing and related advertising strategies. The forecasting instrumental base requires the use of various flexible research methods that take into account the qualitative and quantitative nature of the problem. Based on this, one of the modern paradigms of quantitative modeling is proposed - multi approach modeling on the AnyLogic system platform.

In this study, a hypothesis on the feasibility of forming an advertising strategy for a company based on forecasting the duration of the stages of the product life cycle and the dynamics of target audiences (product flows) through modeling due to the inability to obtain a unique analytical solution is put forward. The author substantiates the possibility of creating strategic advertising solutions using a simulation model, taking into account the non-linear nature of the processes under study and numerous feedbacks.

From the point of view of this problem, a review of existing research results in the following areas was made:

- Analysis of commodity (assortment) policy of pharmaceutical enterprises.

- Research of target audiences (sectors of the market) for which advertising of pharmaceutical products is directed.

- Investigation the effectiveness of advertising: its impact on the current demand for products, reputation, the final results of the companies works.

- Modeling advertising strategies for pharmaceutical companies. In particular, existing applied imitations in this area.

A significant range of domestic and foreign studies is devoted to various aspects of the formation of the product policy of pharmaceutical enterprises.

The classification of pharmaceutical products and the management of its assortment are raised 
in $[1,2]$. In [1], as part of the study of models of marketing-oriented management of pharmaceutical enterprises, a classification model for a dynamic assortment of pharmaceutical products was proposed and some aspects of product portfolio management were considered. In [2], the classification of products according to the characteristics of the product market was improved; the features of pharmaceutical products as an object of product innovation policy are investigated. Particular emphasis is placed on differences in the advertising of products, especially in the pharmaceutical market.

The process of making managerial decisions in the formation of the product portfolio is investigated in [3]. Attention is drawn to the processes of passing the stages of the life cycle, especially the stages of research and development. The author emphasizes that the ideal structure of the product line is determined by the cost of developing medicines, the likelihood of their survival in the testing and approval process, the duration of the market and the expected profitability. The use of optimization methods in determining the composition and structure of the product portfolio of a pharmaceutical company is proposed. Minimizing the level of risk and maximizing portfolio returns are quite widespread and are offered as target functions. However, in addition to formally analytical, the need for further use of fuzzy methods based on the use of available information from previous precedents is emphasized. Although the work contains references only to some aspects of pharmaceutical advertising, a dynamic interactive approach to the formation of a product portfolio is of interest due to the prism of assessing the stages of the life cycle of individual products.

Studies conducted at the University of Georgia (USA) are devoted to the goals of the formation and management of product portfolios of pharmaceutical companies [4]. The work is devoted to the features and complexity of forming portfolios in a merger; integration of portfolio management processes. The results of extensive empirical studies allow us to conclude that it is ne- cessary to attract a special mathematical base for predicting the results of sales of product portfolios in a dynamic pharmaceutical market.

A modern approach to managing a pharmaceutical portfolio in conditions of limited resources was proposed in [5]. The development is based on the implementation of a hybrid approach that combines several modeling methods and creates a complex environment to reflect the dynamic behavior of the market. According to the authors, it is advisable to use both purely analytical and simulation methods with varying degrees of process aggregation. The main hypothesis put forward in the work, the desire to optimize the pharmaceutical portfolio (in particular, from the point of view of distribution and use of limited resources of companies), is realized only if a unified objectoriented modeling is created. a complex that can be adapted to the specifics of specific enterprises in the industry.

One of the most time-consuming and regular research in the field of strategic advertising is the study of target groups. For the pharmaceutical market, this process is complicated by a high level of segmentation and dynamism. Pharmaceutical products have a huge assortment and significant differences in the organization of production processes, control, legal support, promotion, etc. In addition, progress in the field of pharmacology contributes to the emergence of new innovative medicines; the market is also replenished with many related products.

Pharmaceutical companies around the world spend a lot of money on researching the target audience. So, in [6] the results of the analysis of the relationship of marketing strategies of a number of leading companies with the specifics of target groups of users of pharmaceutical products, in particular, its innovative segments, are presented. In [7], the results of studying the behavior of the target audience of users with generic medicines are presented. The constructed behavior model takes into account the advantages of Italian consumer groups, which differ in numerous ways: demography, self-identification, previous 
behavior, risk sensitivity, preferences for specific brands, etc.

The geography of such studies is great. As illustrative examples of "field" experiments, one can cite the impact of reacting target user groups on pharmaceutical advertising (direct and contact) [8-10]. One of the most problematic and controversial aspects of strategic decision making is determining its effectiveness. The following sources are illustrative examples of research in this area.

An empirical studies of 25 large "field" experiments with the total costs of digital advertising worth more than 2.8 million US dollars carried out with large American retailers that reach millions of customers are presented in [11]. The results obtained proved the impossibility of unambiguously determining the impact of advertising costs on the final results. The studies used economic and statistical methods, and in total more than 10 million person-weeks were used to ensure the informativeness of advertising experiments.

An analysis of the influence of advertising in terms of attracting investments is given in [12]. The focus of this empirical study was the promotion of stock-oriented products. An experiment was conducted with a representative sample of real investors to test the effect and study the main advertising mechanisms. The results proved that emphasizing the characteristics of a product in advertising for investors increases their subjective assessment of specific products and their interest in investing in company stocks. In this case, the effect is manifested regardless of the presence of factors related to the previous perception of brands. The authors came to the conclusion that the obtained data identify and confirm various mechanisms of the impact of advertising on investors, however, the relative magnitude of the influence cannot be generalized.

Noteworthy is the attempt to obtain an analytical solution to one of the specific tasks of evaluating the effectiveness of advertising in [13]. The paper analyzes a dynamic, continuous model of optimal management of advertising costs. It takes into account the late reaction of users and the im- pact of advertising on purchases that were made earlier. It takes into account the influence of past sales and advertising (accumulated over certain periods of time) to determine the impact of advertising. The solution to the optimization problem is reduced to solving a system of nonlinear integral equations of Volterra type and an integral quality functional. The authors prove the existence of a solution to the problem of maximizing company profits in the planned period with a limited advertising budget and the presence of a functional dependence that reproduces the reaction of the target audience. The authors discuss the functional dependence of current demand on the accumulated reputation of the company and the accumulated effect of advertising. However, the attached results of the application of the proposed model are not presented.

A detailed analysis of the existing mathematical apparatus for studying dynamic advertising is given in [14], where the authors made a reference to a significant number of literary sources (134 references). As an example of the use of model applications in the field of pharmaceutical advertising, we can cite the work [15-18] and others.

The use of imitation research methods aimed at advertising is quite limited today. The range of modeling applications dedicated to reproducing various aspects of advertising processes can be represented by the following sources.

A simulation model that focuses on the study of the use of advertising in the process of promoting products of an Internet enterprise is proposed in [19]. The result of the experiments is the selection of the optimal set of advertising methods in the conditions of minimizing costs. The model is implemented in the AnyLogic system environment. Issues of advertising and pricing policies of Internet providers are raised in [20], which proposes a model for reproducing user behavior in the Internet services market. Modeling of advertising budgets within the framework of general advertising strategies of enterprises is presented in [21].

Although the presented model applications do not relate exactly to the pharmaceutical industry, 
specific blocks and technologies of simulation experiments can be adapted to its specifics.

International platforms that regularly present model applications using various modeling paradigms aimed at solving a wide range of problems, in particular in the context of the problem under consideration, are: Winter Simulation Conference [22], International System Dynamics Conference [23], the German-speaking community of ASIM simulators [24], IMMOD "Simulation, Theory and Practice" [25], EUROSIM European Congress [26], webinars and publications of one of the world's leading corporations in the modeling industry - AnyLogic Company [27].

Unsettled issues. Studies of various aspects of the formation and implementation of advertising strategies are usually conducted separately, which violates the complex perception of the problem and reduces the reliability and reliability of the results. On the other hand, intermediation in advertising actions and dependence on components of the general strategy of a company (production, goods, innovations, marketing, finance, investment, marketing) necessitate taking their specificity into account when making strategic advertising decisions. Practice proves that the tasks set are relevant, and their final solution is far from complete - this is confirmed by the results of many empirical "field" experiments.

In the context of this work, we are talking about the need to focus on a comprehensive review of the processes of dynamic strategic advertising and the formation of a product portfolio of a pharmaceutical company (taking into account the peculiarities of the stages of the life cycle of individual nomenclature items). At the same time, it is necessary to reduce the cost of experiments in order to make them accessible to a wide range of enterprises. In accordance with this, not only the concept of research is important, but also the mathematical tools that are used.

This review proves that in most cases the mathematical basis for decision making in the advertising field consists of economic-statistical, optimization methods and application models based on them. But this greatly limits the possibility of obtaining adequate results in the absence of stable, equilibrium trends, clear algorithmic dependencies; the presence of recursive formulas; lack of necessary retrospective information.

Therefore, it is advisable to use modern modeling paradigms on appropriate software platforms to create simulation models for the development of managerial decisions in a dynamic indefinite environment. Although improving the tools for customizing and implementing simulation models, as well as plans for conducting experiments, is an ongoing process, modeling tools will help expand the scope of the problem, reduce the duration and cost of research. The use of multicast modeling paradigms on software platforms of integrated systems, as well as Internet technologies for the application of ready-made models, creates a single research space and implements a systematic approach to conducting simulation studies. Today, AnyLogic is one of the most effective world-class software platforms that supports the main modern modeling paradigms (Discrete Event, Agent and System Dynamics) and their combinations.

The aim of the article is to study decision-making processes in the field of strategic advertising of pharmaceutical enterprises using a multi-level paradigm of simulation on the AnyLogic software platform.

Currently, according to the Law of Ukraine "On Advertising", there are restrictions on the advertising of prescription medicines. Advertising prescription medicines can be used taking into account the basic principles of advertising, all legal requirements regarding its form and content, but only among a limited number of items - it is placed in specialized publications intended for medical institutions and doctors, and is also distributed at seminars, conferences, symposia on medical topics. Therefore, the study examines the advertising activities of enterprises in relation to overthe-counter (original and generic) medicines.

Considering medicines as a category of market product, it is also important to understand the terms "original" and "generic" (reproducible) medi- 


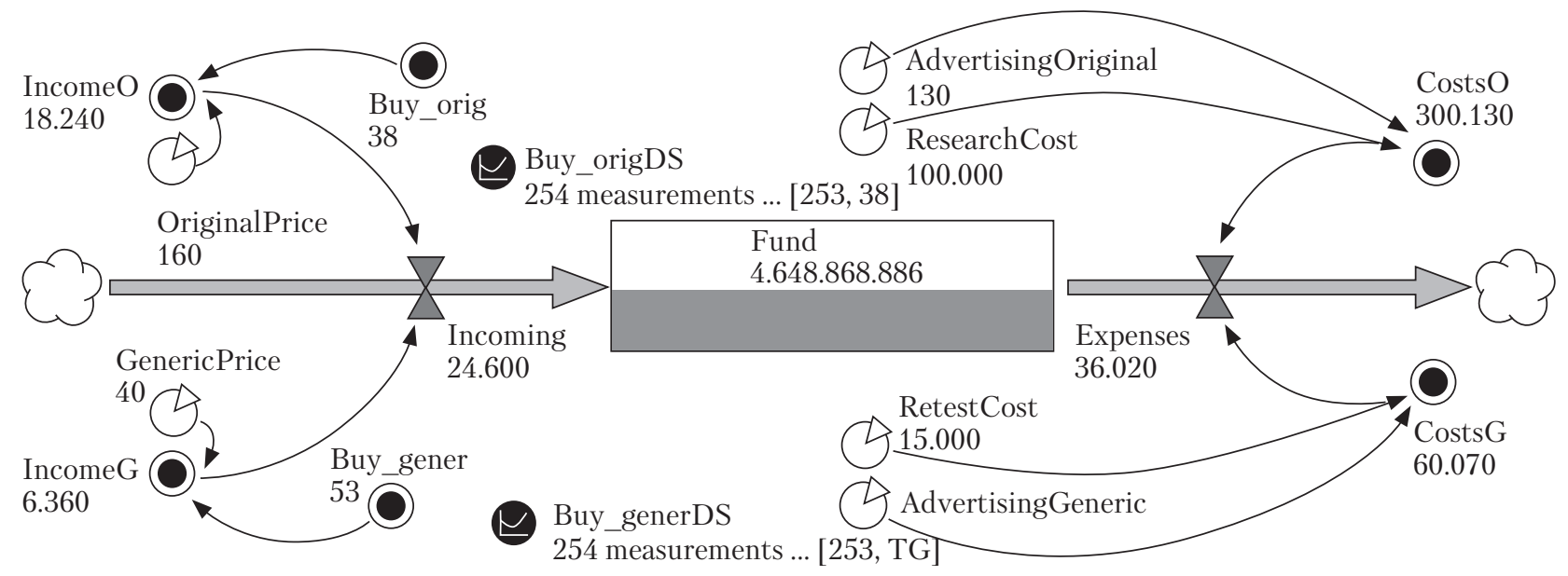

Fig. 1. Block of continuous simulation

Source: developed by authors.

cine. An original (innovative) medicine is a product first introduced on the pharmaceutical market, containing a new synthesized or otherwise obtained active pharmaceutical ingredient that is approved for medical use and patented for a certain period of time. A reproducible medicine (generic) is a copy that, in its therapeutic efficacy and safety, corresponds to an innovative (original) medicine. It is manufactured by a pharmaceutical company after the expiration of patent protection [28].

As part of the creation of a model complex for the marketing activities of a pharmaceutical company, an analysis of the advertising strategies of Farmak OJSC, the leader of pharmaceutical manufacturers of various pharmacotherapeutic groups in Ukraine, was carried out. The company occupies $6.5 \%$ of the pharmaceutical market among all manufacturers (including foreign manufacturers) and $16.8 \%$ of the pharmaceutical market among Ukrainian manufacturers. The main sources of incoming data are the State Statistics Service of Ukraine [29] and the official Farmak website [30].

The simulation model-simulator developed as part of the complex is aimed at developing the following solutions in the field of strategic advertising:

- investigation the optimal level of prices for the product assortment in order to maximize revenue from sales;
- minimize advertising budget and its distribution to promote original and generic medicines;

- monitoring the effectiveness of research new and re-production of existing medications, depending on the duration of the life cycle;

- determining the preferences of potential buyers depending on the level of demand and prices for assortment;

- monitoring and forecasting the reaction of the target audience to product advertising, tracking the level of information about the product, etc.

The financial elements of the model in the work are presented fragmentarily in Fig. 1.

The system-dynamic block shown in Figure 1 is designed to simulate the company's capital in real time (within the task), the analysis of the movements of which allows us to draw conclusions about the intensity of the sales and investment processes in specific areas. According to this, the contents of the "Fund" device storage are replenished with income from the sale of original and generic medicines and are reduced with the costs of their research and advertising.

Factors affecting the level of income are directly related to the behavior of the user - potential buyer. The buyer in the system can be in four states: TargetAudience, PotentialBuyers, BuyOriginal and BuyGeneric (Fig. 2). The built-in 


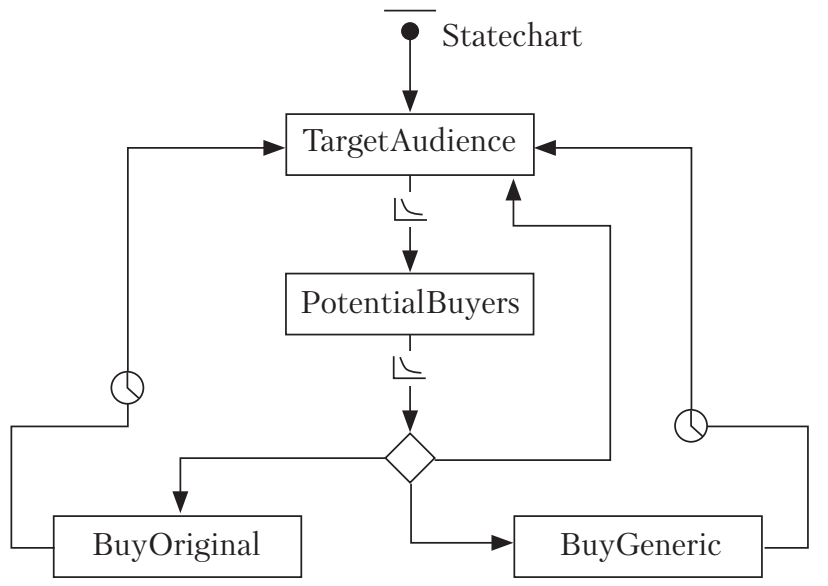

Fig. 2. Buyers State Diagram Source: developed by authors.

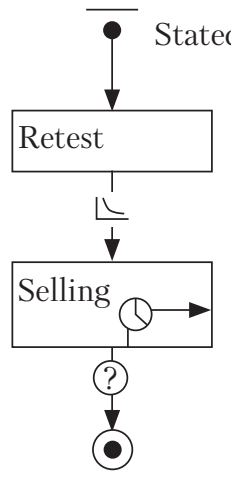

Fig. 3. State Diagram of generic medicines Source: developed by authors.

graphic tools AnyLogic are used in the course of dynamic simulation objects - the schematic representation of elements and the change of colors for tracking states.

The process of informing the target audience is described by the model of Nerlow-Errow (N-A model), which has the form of differential equation of the 1st order:

$$
\frac{d A}{d t}=b \cdot q(t)-k \cdot A,
$$

where $A(t)$ - awareness about product (number of informed people about product in period $t$ ); $q(t)$ - advertising activity (advertising costs in period $t$ ); $b$ - advertising effectiveness (rating of the source of advertising); $k$ - the speed of obli-

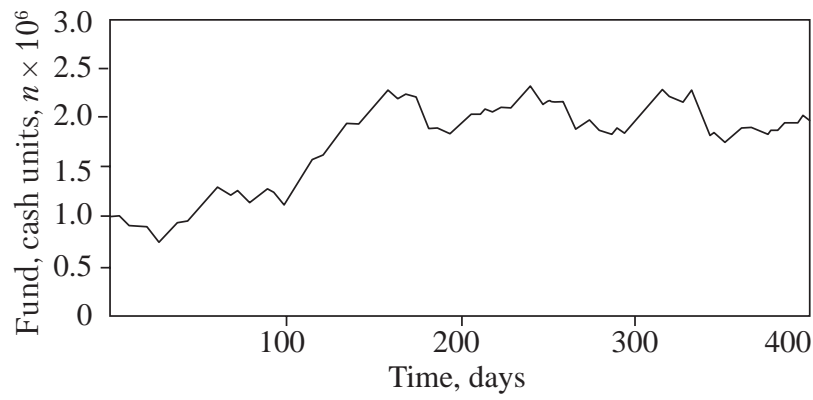

Fig. 5. Fund level during model time

Source: compiled by authors based on simulation results.

vion of information. In the simulation model this coefficient is defined as a random variable of 10 to $80 \%$, which is due to the forgetting curve of Ebbinghaus.

The process of buying medicines and switching to appropriate states occurs depending on the stages life cycle of preparats. So, if the buyer has enough money, but at the time of purchase there is no necessary medicine on the market, the buyer will choose an analog or completely refuse the purchase. If the buyer hasn't enough money, he will refuse the purchase.

Life cycle stages of generic and original medicines are presented in system in the form of corresponding diagrams of states using agent modeling (Fig. 3 and Fig. 4).

Original medicines in the system can be in four states: Research, Testing, Registration and Selling, while generic medicines - only in two states: Retest and Selling. This is due to the fact that the original medicines undergo a full cycle of preclinical and clinical studies and mandatory registration.

All blocks of the model are interconnected, which enables adjusting the necessary amount of costs for advertising tools; determination of the reasonable cost of pharmaceutical products; optimization of the effectiveness of marketing costs; maximization of income from advertising campaigns and the number of regular customers; $\mathrm{Cal}-$ culation of sales in physical terms. The simulation model provides the opportunity to conduct computer experiments with the aim of introducing variations of significant environmental factors 


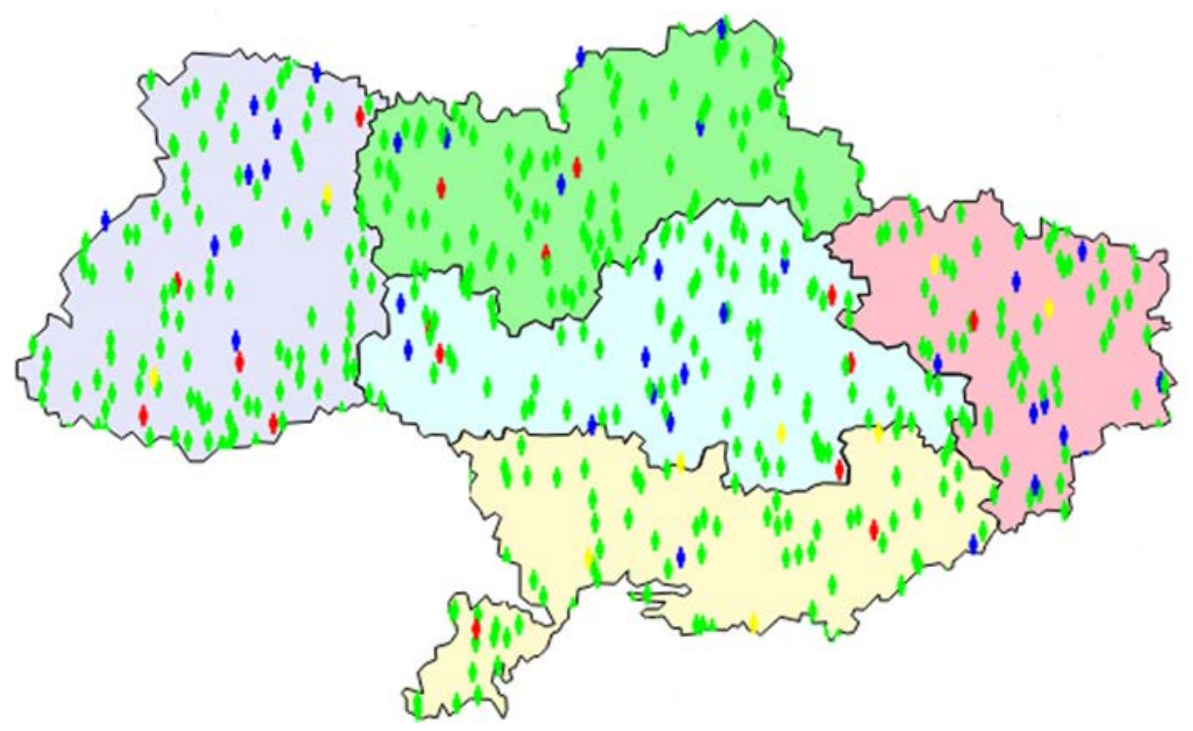

Fig. 6. Activity of buyers during the model time

Source: compiled by authors based on simulation results.

to select the optimal values while minimizing the cost of advertising campaigns. The model makes it possible to quickly analyze the current state of affairs, optimize the current activities of the enterprise, and also develop a plan for further actions.

The decision support process is driven by various types of model experiments. AnyLogic tools enable conductinig the following experiments by type of analysis: Standard (simple) experiment; Variation of parameters; Optimization; Comparison of "runs"; Sensitivity analysis; Calibration; Monte Carlo; Non-standard. The first three types of experiments are considered in this study. A simple experiment launches a model with given parameter values, supports virtual and real-time modes, animation, and model debugging. So, the change in the level of capital during the modeling period (1 year) is shown in Fig. 5.

Figure 5 shows that in the first half of the year the company suffers losses, and in the second half it starts to make a profit. Because significant research and advertising costs are incurred when new medicines are prepared to enter the market, and only after some time, buyers begin to recognize and actively buy a product.

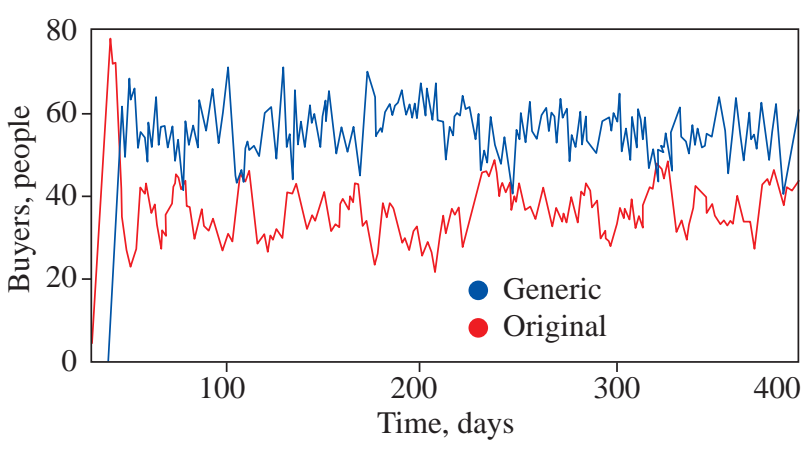

Fig. 7. The level of buyers of original and generic medicines Source: compiled by authors based on simulation results.

The activity of the target audience and the transition to the state of customers when performing the Simple experiment during the model time (1 year) are shown in Fig. 6. This fragment represents a generalized situation by regions of Ukraine.

So, in state TargetAudience agent is marked in green, in state PotentialBuyers - in yellow, in BuyOriginal and BuyGeneric states - in red and blue respectively. With the built-in "Time schedule" tool, it can be graphically monitored the level of buyers original and generic medicines (Fig. 7). This enables a timely response to changes in the situation, make decisions about in- 


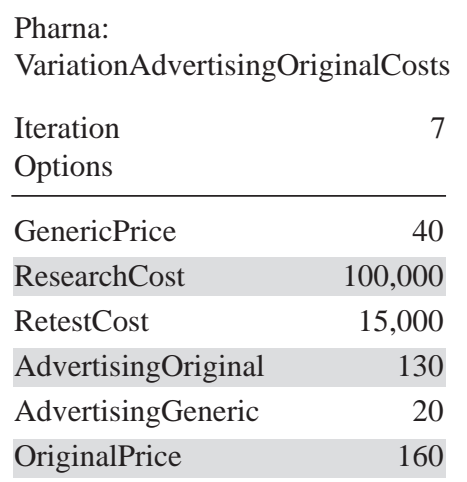

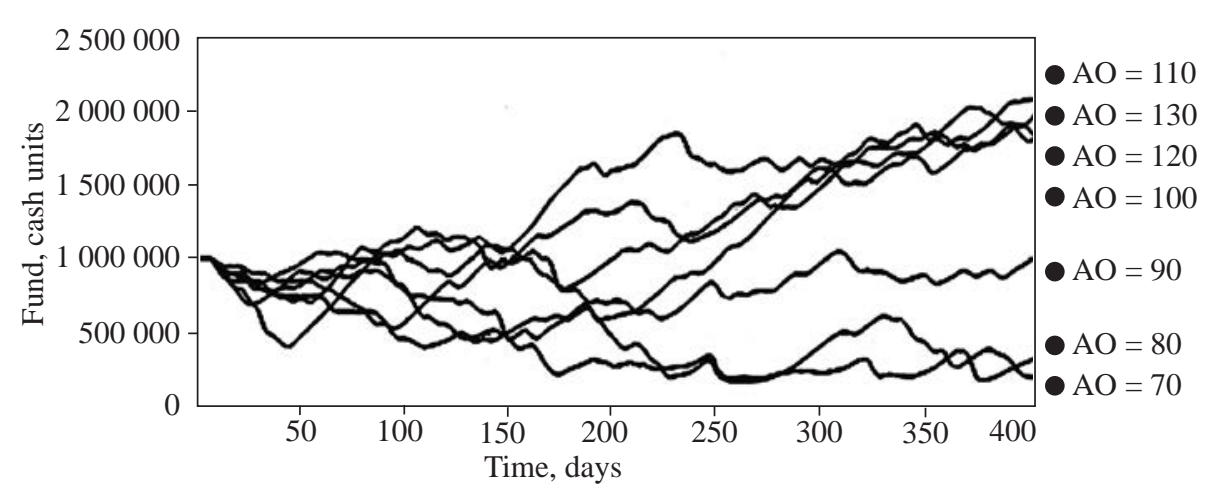

Fig. 8. First experiment of parameters variation

Source: compiled by authors based on simulation results.

Pharna:

VariationA dvertisingO riginalC osts

Iteration

Options

\begin{tabular}{lr}
\hline GenericPrice & 40 \\
ResearchCost & 100,000 \\
RetestC ost & 15,000 \\
AdvertisingOriginal & 100 \\
AdvertisingG eneric & 70 \\
OriginalPrice & 160
\end{tabular}

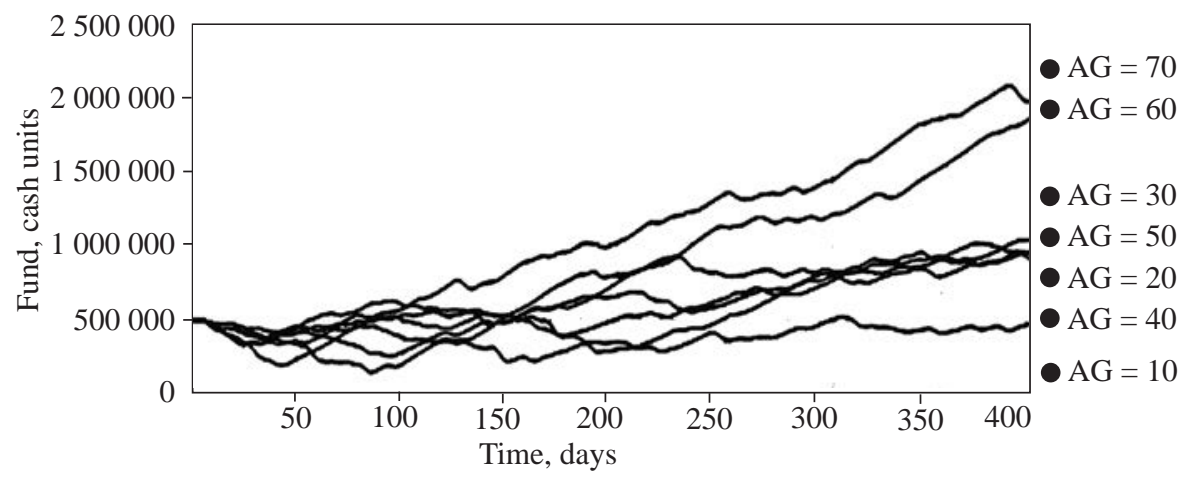

Fig. 9. Second experiment of parameters variation

Source: compiled by authors based on simulation results.

creasing or decreasing the intensity of advertising of a certain type of medicine.

As Fig. 7 shows, the sales number of generic medicines in kind pr evails over the original. This is explained by a much lower price and a larger assortment.

Experiment Variation of parameters performs several "runs" of a model with variations of one or more parameters, with the ability to use replication. For the constructed model it was decided to conduct two experiments Variation of parameters with change of only one parameter. The Fund serves as a factor, which changes under the influence of the chosen parameter.

First experiment. The advertising costs of original medicines are acting as a parameter, which changes (Fig. 8).
Fig. 8 shows that at advertising costs of generic medicines equal to 20 cash units the maximum value of fund is achieved when advertising costs of original medicines equal to 110 cash units, and the minimum value of fund is achieved when advertising costs of original medicines equal to 70 cash units.

Second experiment. The advertising costs of generic medicines are acting as a parameter, which changes (Fig. 9).

Fig. 9 shows that at advertising costs of original medicines equal to 100 cash units the maximum value of fund is achieved when advertising costs of generic medicines equal to 70 cash units, and the minimum value of fund is achieved when advertising costs of generic medicines equal to 10 cash units. 


\begin{tabular}{lr|r} 
Pharna: Optimization & & \\
& Current & B est \\
\hline Iteration & 500 & 95 \\
Functional: & 101 & 120 \\
\hline Options & & Copy best \\
\hline GenericPrice & 40 & 40 \\
ResearchC ost & 100,000 & 100,000 \\
RetestC ost & 15,000 & 15,000 \\
Original Price & 140 & 140 \\
\hline A dvertisingO riginal & 150 & 110 \\
A dvertisingG eneric & 30 & 90
\end{tabular}

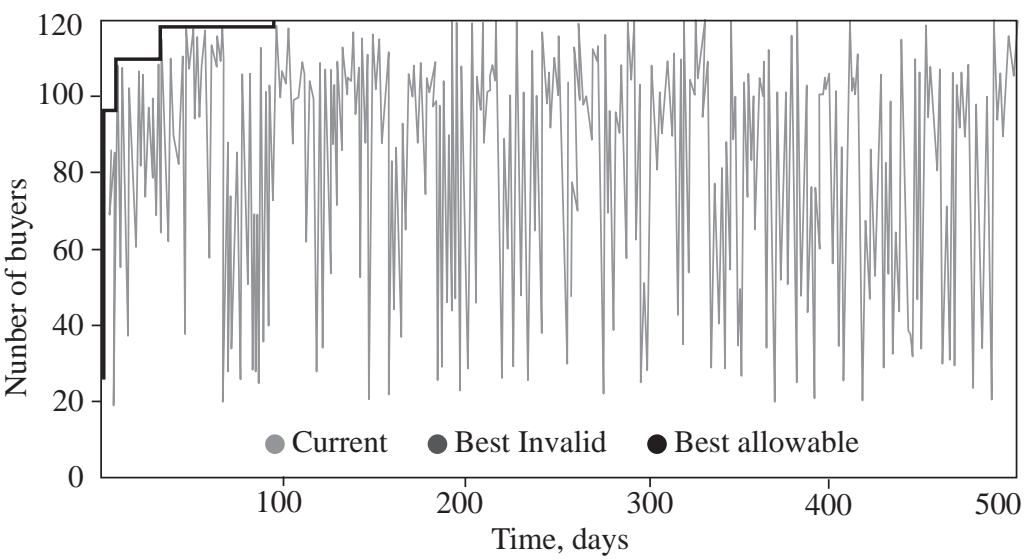

Fig. 10. Optimization experiment of maximizing number of buyers

Source: compiled by authors based on simulation results.

This type of experiment involves fluctuations in the main factor from a parameter change. These prognostic values help make strategically important decisions to achieve certain goals about setting the level of advertising costs for each type of medicine, the level of prices for medicines, etc.

An optimization experiment seeks the value of parameters at which the optimal value of a given objective function is achieved. There may be a number of restrictions on the parameter values and model variables. An optimization progress graph is displayed.

For this model, the target function of maximizing number of buyers for both types of medicines was established. The result of the optimization experiment is shown in Fig. 10.

This Optimization experiment performed 500 iterations in which the price and advertising costs of both types of medicines were changed. The best option is iteration \#95, for which the following parameter values were selected: objective function - 120; GenericPrice - 40, OriginalPrice -140 ; AdvertisingOriginal - 150, AdvertisingGeneric -30 . Likewise, the system allows for optimization experiment to maximize revenues from medicine sales, to minimize advertising costs, to consider each type of medicine separately, etc. Thanks to such an experiment, a pharmaceutical company can quickly find the parameters in which the necessary market situation will be reali- zed - an increase or decrease in strategically important factors.

Summarizing the above, it can be argued that the simulation model-simulator is an effective basis for supporting decision-making in the formation of advertising strategies for pharmaceutical companies. Using this model, you can track consumer behavior and stages of the drug life cycle in real time, taking into account the volatility and instability of the pharmaceutical market. Reproduction by modeling the stochastic nature of the investigated processes and the dynamics of their changes provides a sufficient level of adequacy of the developed application model, increases the reliability of the results.

Obtaining statistical and predictive values in various situations with the ability to configure specific parameters is available due to the presence of various types of experiments. The model application is designed for repeated testing of situational experiments to monitor the saturation of the product market, the promotion of goods in the regions of the country (which is especially interesting for innovative medicines), the level of awareness of the target audience, the impact of advertising efforts and a significant number of other parameters presented in the system. In general, this helps to optimize the budgets of advertising companies and the technology of their distribution over time, especially in a 
strategic perspective. Due to the openness and modularity of the model-simulator, the conditions for its adaptation to the specifics of the work of concrete industry enterprises are created.

Further studies are planned in the following areas:

- a detailed forecast of financial results and risks of implementing specific advertising strategies;

- strengthening the instrumental platform for experiments using cloud technologies that will integrate the processes of making strategic advertising decisions of pharmaceutical companies at the industry level;

- focus on advertising strategies for innovative types of pharmaceutical products;

- enhancing the visibility of dynamic modeling experiments using the HTML5 animation rendering engine;
- take into account changes in the company's reputation (by introducing dynamic parameters-indicators of market situations into the model) and competitor's actions (reproduction of generalized advertising strategies of competitors according to the model with forecasting their influence on the results of product promotion of the enterprise under study) in the process of making strategic decisions;

- development and testing of technology for embedding the developed simulation models in the existing information flows of pharmaceutical companies, that is, integration with CRM or ERP systems operating at enterprises.

The main area of research is to increase the experimental base by expanding the range of studied enterprises of the pharmaceutical industry of Ukraine.

\section{REFERENCES}

1. Shabelnyk, T. V. (2016). Models of marketing-oriented management of the pharmaceutical enterprise. (Doctoral dissertation). Poltava [in Ukrainian].

2. Melnik, I. M., Holysheva, E. O. (2017). Features of marketing complex in the system of innovative development of pharmaceutical enterprises. Marketing and Management of Innovations, 4, 27-40 [in Ukrainian]. https://doi.org/10.21272/ mmi.2017.4-02

3. Jekunen, A. (2014). Decision-making in product portfolios of pharmaceutical research and development - managing streams of innovation in highly regulated markets. Drug Design, Development and Therapy, 8, 2009-2016. https://doi. org/10.2147/DDDT.S68579

4. Jones, C. M. (2016). Managing Pharmaceutical Research And Development Portfolios: An Empirical Inquiry Into Managerial Decision Making In The Context Of A Merger. (Doctoral dissertation). Georgia State University.

5. Solo, K., Paich, M. A. (2003). Modern Simulation Approach for Pharmaceutical Portfolio Management. URL: https:// www.anylogic.ru/upload/iblock/6d4/6d45074aefb2d023be20115ec9c77301.pdf (Last accessed: 23.02.2019).

6. Kalotra, A. (2014). Marketing strategies of different pharmaceutical companies. Journal of Drug Delivery E Therapeutics, $4(2), 64-71$.

7. Zerbini, C., Luceri, B., Vergura, D. (2017). Leveraging consumer's behaviour to promote generic drugs in Italy. Health Policy, 121(4), 397-406. https://doi.org/10.1016/j.healthpol.2017.01.008

8. Pujari, N. M., Sachan, A. K., Kumari, P., Dubey, P. (2016). Study of Consumer's Pharmaceutical Buying Behavior Towards Prescription and Non-Prescription Drugs. Journal of Medical and Health Research, 1(3), 10-18.

9. Biswas, K., Ferdousy, U. K. (2016). Influence of Pharmaceutical Marketing on Prescription Behavior of Physicians: A Cross-sectional Study in Bangladesh. Journal of Accounting \& Marketing, 5(2), 1-4. http://dx.doi.org/10.4172/21689601.1000160

10. Costea, D., Carter, F., Chou, S.-Y., King, A. (2012). Is Advertising Effective or Not? Evidence from the Pharmaceutical Market. NMIMS Management Review, 12, 9-28.

11. Lewis, A., Rao, J. M. (2015). The unfavorable economics of measuring the returns to advertising. The Quarterly Journal of Economics, 1941-1973.

12. Aspara, J., Chakravarti, A. (2015). Investors' reactions to company advertisements: the persuasive effect of product-featuring ads. European Journal of Marketing, 49(5/6), 943-967. https://doi.org/10.1108/EJM-11-2013-0661

13. Lutoshkin, I. V., Iamaltdinova, N. R. (2016). The existence of a solution to the problem of managing advertising expenses with distributed delay. The Bulletin of Irkutsk State University, 18, 48-59 [in Russian]. 
14. Huang, J., Leng, M., Liang, L. (2012). Recent Developments in Dynamic Advertising. European Journal of Operational Research, 220(3), 591-609. https://doi.org/10.1016/j.ejor.2012.02.031

15. Ahmed, R. R., Vveinhardt, J., Streimikiene, D., Awais, M. (2016). Mediating and marketing factors influence the prescription behavior of physicians: An empirical investigation. Amfiteatru Economic, 18(41), 153-167.

16. Avagyan, V., Landsman, V., Stremersch, S. (2017). Marketing models for the life sciences industry. International Series in Operations Research and Management Science, 254, 385-430. https://doi.org/10.1007/978-3-319-56941-3_13

17. Bardey, D., Bommier, A., Jullien, B. (2010). Retail price regulation and innovation: Reference pricing in the pharmaceutical industry. Journal of Health Economics, 29(2), 303-316. https://doi.org/10.1016/j.jhealeco.2009.11.015

18. Leeflang, P. S. H., Wieringa, J. E. (2010). Modeling the effects of pharmaceutical marketing. Marketing Letters, 21(2), 121-133. https://doi.org/10.1007/s11002-009-9092-3

19. Berezovskaia, E. A., Plotnikov, C. A. (2015). Simulation of an advertising campaign the Internet-enterprise in the environment of AnyLogic. International Scientific Joumal, 9, 86-90 [in Russian].

20. Katalevskii, D. Y., Solodov, V. V., Kravchenko, K. K. (2012). Modeling of consumer behavior. Artificial societies, 7(1/4), 34-59 [in Russian].

21. Pesikov, E. B. (2003). Estimation of efficiency and degree of marketing strategies risk of the enterprise on the simulation modeling basis. The Practice of Simulation Modeling (IMMOD-2003), 2, 110-115 [in Russian].

22. Winter Simulation Conference. URL: http://meetings2.informs.org/wordpress/wsc2018/ (Last accessed: 11.02.2019).

23. The $36^{\text {th }}$ International Conference of the System Dynamics Society. URL: https://www.systemdynamics.org/past-conference-2018 (Last accessed: 13.02.2019).

24. Arbeitsgemeinschaft Simulation. URL: https://www.asim-gi.org/asim/ (Last accessed: 12.02.2019).

25. Eighth All-Russian Scientific and Practical Conference "Simulation modeling. Theory and practice" IMMOD-2017. URL: http://simulation.su/static/ru-immod-2017.html (Last accessed: 11.02.2019).

26. Proceedings from "The Federation of European Simulation Societies". URL: https://www.eurosim.info/eurosim/ (Last accessed: 15.02.2019).

27. Offical Site of AnyLogic Company URL: http://www.anylogic.com/ (Last accessed: 11.12.2018).

28. Levytska, O. (2016). Medicinal products as objects of the pharmaceutical market (part 2). Pharmacist Practitioner, 2. URL: http://fp.com.ua/articles/likarski-zasobi-yak-ob-yekti-farmatsevtichnogo-rinku-chastina-2/ (Last accessed: 20.01.2019).

29. State Statistics Service of Ukraine. URL: http://www.ukrstat.gov.ua/ (Last accessed: 21.12.2018).

30. Offical Site of OJSC “Farmak". URL: http://www.farmak.ua/ (Last accessed: 05.12.2018).

Стаття надійшла до редакціi / Received 26.02.19

Статтю прорецензовано / Revised 09.09.19

Статтю підписано до друку / Accepted 07.11.19

Б.В. Буркинський ${ }^{1}, 3 . М$. Соколовська ${ }^{2}$,

О.Б. Альохін ${ }^{2}$, Н.І. Хумарова ${ }^{1}$, I.В. Капустян ${ }^{2}$

${ }^{1}$ Інститут проблем ринку та економіко-екологічних досліджень НАН України, Французький бульвар, 29, Одеса, 65044, Україна,

+380 48722 6611, burkinskij@nas.gov.ua

${ }^{2}$ Одеський національний політехнічний університет,

просп. Шевченка, 1, Одеса, 65044, Україна,

+380 48705 8358, nadin_zs@te.net.ua

ІНСТРУМЕНТИ ПРИЙНЯТТЯ РІШЕНЬ В ГАЛУЗІ

СТРАТЕГІЧНОЇ РЕКЛАМИ ФАРМАЦЕВТИЧНИХ ПІДПРИЕМСТВ

Вступ. Розвиток сучасних інформаційно-комунікаційних технологій сприяє удосконаленню рекламних стратегій, як ефективних інструментів фармацевтичного маркетингу.

Проблематика. Необхідність врахування нелінійного динамічного характеру рекламних процесів, наявності впливу численних стохастичних факторів ринкового оточення фармацевтичних підприємств при неможливості отримання однозначного аналітичного рішення актуалізують проблему залучення спеціального математичного апарату дослідження.

Мета. Дослідити процеси прийняття рішень в галузі стратегічної реклами фармацевтичних підприємств 3 використанням апарату імітаційного моделювання. 
Матеріали й методи. Дослідження базується на використанні багатопідходної парадигми імітаційного моделювання в програмному середовищі системи AnyLogic. Як аналітичний матеріал використано дані фармацевтичної компанії ВАТ «Фармак».

Результати. Обгрунтовано доцільність залучення методів імітації як інструментів прийняття стратегічних рекламних рішень. Запропоновано імітаційну модель-тренажер, розроблену з використанням комбінації агентного та системно-динамічного підходів на програмній платформі AnyLogic. Процес прийняття рішень проілюстровано результатами різних типів імітаційних експериментів. Окреслено основні напрямки використання моделі-тренажера: моніторинг і прогнозування реакції цільових аудиторій на товарну рекламу; контроль ефективності досліджень нових та перевипуску існуючих препаратів згідно з реакцією ринку та вподобаннями потенційних клієнтів; оптимізація рекламного бюджету з обгрунтуванням доцільності його перерозподілу між оригінальними та генеричними препаратами.

Висновки. Доведено ефективність використання імітаційних моделей-тренажерів як інструментів формування рекламних стратегій. Розробку може бути рекомендовано для впровадження фармацевтичними компаніями.

Ключевые слова: рекламна стратегія, фармацевтичне підприємство, імітаційне моделювання, модель-тренажер, імітаційні експерименти. 